\title{
PENINGKATAN PENGETAHUAN SISWA MENGENAI JAJANAN SEHAT MENGGUNAKAN MEDIA MINICARD
}

\author{
Andini Santoso, Mazarina Devi ${ }^{1}$, Agung Kurniawan ${ }^{2}$ \\ ${ }^{1}$ Dosen Fakultas Teknik Universitas Negeri Malang \\ ${ }^{2}$ Dosen Ilmu Kesehatan Masyarakat Fakultas Ilmu Keolahragaan Universitas Negeri Malang \\ Email: andinsantoso@gmail.com
}

\begin{abstract}
Snacks are holding an important role in providing energy and nutrients intake among school-aged children. Snacks at school that is health less well-guaranteed will potentially bring some effects, which are poisoning, indigestion, and in a long time causing malnutrition. Knowledge enhancement in healthy snacks around children can be done through the health education by using nutritional counseling methods. Nutrition counseling methods in this research were given through the minicard media that is flashcard media that has been modified its size to 12 $\mathrm{cm} \times 10 \mathrm{~cm}$. This research aims to determine students' knowledge in healthy snacks in SDN 02 Mulyoagung, and also created minicard as a counseling media. This research is a quantitative research by using pre-experiment in one group pre-test post-test model. The sample totals are 30 students, whose are 16 students in V grade and 14 students in IV grade that obtained by purposive sampling technique. Data collection that was used is a questionnaire and data analysis which utilized a sample test of nonparametric 2 methods related to Wilcoxon. The results obtained Sig. (2-tailed) of 0,000 which means less than $\alpha(0.025)$. The average value is increased on post-test after giving intervention in nutritional counseling by using minicard media, so it can be concluded that counseling with the minicard media can improve students' knowledge in healthy snacks in SDN 02 Mulyoagung, Kecamatan Dau, Kabupaten Malang.
\end{abstract}

\section{Keywords: Minicard Media, Knowledge, Healthy Snacks, Elementary Students}

\begin{abstract}
Abstrak: Makanan jajanan memegang peranan yang cukup penting dalam memberikan asupan energi dan zat gizi lain bagi anak-anak usia sekolah. Peningkatan pengetahuan tentang jajanan sehat pada anak dapat dilakukan melalui pendidikan kesehatan dengan metode penyuluhan gizi. Metode penyuluhan gizi pada penelitian ini diberikan melalui media minicard, yaitu media flashcard yang telah dimodifikasi ukurannya menjadi $12 \mathrm{~cm} \times 10 \mathrm{~cm}$. Penelitian ini bertujuan untuk mengetahui pengetahuan siswa mengenai jajanan sehat di SDN 02 Mulyoagung, serta menciptakan media penyuluhan minicard. Penelitian ini merupakan penelitian kuantitatif menggunakan pre experiment dengan model one grup pre-test post-test. Sampel berjumlah 30 siswa 16 siswa kelas V dan 14 siswa kelas IV yang diperoleh dengan teknik purposive sampling. Pengumpulan data menggunakan kuesioner dan analisis data menggunakan metode nonparametrik uji 2 sampel berhubungan Wilcoxon. Hasil penelitian didapatkan Sig. (2-tailed) sebesar 0,000 yang berarti kurang dari $\alpha(0,025)$. Terjadi peningkatan rata-rata nilai pengetahuan pada post-test setelah diberikan intervensi berupa penyuluhan gizi dengan minicard, sehingga dapat disimpulkan bahwa penyuluhan menggunakan media minicard efektif dalam meningkatkan pengetahuan siswa tentang jajanan sehat di SDN 02 Mulyoagung Kecamatan Dau Kabupaten Malang. Setelah diadakannya penyuluhan ini diharapkan siswa dapat mengingat informasi yang telah diberikan sehingga mengurangi paparan anak sekolah terhadap makanan jajanan yang tidak sehat dan tidak aman.
\end{abstract}

Kata Kunci: Media Minicard, Pengetahuan, Jajanan Sehat, Siswa Sekolah Dasar 


\begin{abstract}
Salah satu sasaran pokok Rencana Pembangunan Jangka Menengah Nasional (RPJM) Kementerian Kesehatan pada Program Indonesia Sehat 2015-2019 adalah meningkatnya status kesehatan gizi ibu dan anak. Menurut Hasdianah (2012) sumber daya manusia yang berkualitas sangat dipengaruhi oleh asupan gizi. Gizi menjadi bagian sangat penting dalam pertumbuhan dan perkembangan. Gizi di dalamnya memiliki keterkaitan yang erat dengan kesehatan dan kecerdasan. Status gizi yang baik pada anak-anak perlu mendapatkan perhatian lebih karena ketika status gizi anak buruk dapat menghambat pertumbuhan fisik, mental maupun kemampuan berfikir.
\end{abstract}

Menurut Fudyartanta (2012) anak Sekolah Dasar adalah anak yang berumur 7-13 tahun yang telah memiliki kesadaran dan kewajiban akan aturan, kemampuan bergaul, dan haus akan pengetahuan baru. Anak Sekolah Dasar seringkali membeli jajanan di sekolah. Kebiasaan jajan di sekolah terjadi karena 3-4 jam setelah makan pagi perut akan terasa lapar kembali (Sihadi, 2004). Anak cenderung untuk membeli jajanan yang tersedia paling dekat dengan keberadaannya (Peilin, 2004). Anak Sekolah Dasar belum mengerti cara memilih jajanan yang sehat sehingga berakibat buruk pada kesehatannya. Jajanan anak sekolah yang kurang terjamin kesehatannya berpotensi menyebabkan keracunan, gangguan pencernaan, dan jika berlangsung dalam waktu yang lama akan menyebabkan status gizi yang buruk (Suci, 2009).

Meningkatnya waktu anak yang dihabiskan di sekolah membuat anak lebih terpengaruh oleh lingkungan yang mendorong anak harus memiliki keputusan yang baik dalam memilih makanannya (Lindsay, 2006). Berbagai studi menunjukkan konsumsi makanan ringan yang tidak sehat, fast food, dan minuman ringan meningkat (Lin $\mathrm{W}$ et al, 2007). Oleh karena itu, anak sekolah menjadi kelompok yang paling rentan karena masih rendahnya pengetahuan mereka tentang keamanan pangan (Nam, 2010).

Makanan jajanan menurut Food Agricultural and Organization (FAO) makanan jajanan adalah makanan dan minuman yang dipersiapkan atau dijual oleh pedagang kaki lima di jalanan dan di tempat-tempat umum yang langsung dikonsumsi tanpa pengolahan atau persiapan lebih lanjut (WHO, 2006). Makanan jajanan merupakan faktor yang penting bagi pertumbuhan anak, karena jajanan menyumbangkan energi dan zat gizi yang diperlukan untuk pertumbuhan anak, sehingga jajanan yang berkualitas baik akan mempengaruhi kualitas makanan anak (Murphy, 2007). Kajian makanan jajanan di Afrika menyebutkan bahwa makanan jajanan memberikan kontribusi energi sepertiga dan seperempat vitamin dan mineral dari konsumsi harian (Bremmer dll. 1990 Pratap \& Booluck 2006). Oleh sebab itu, makanan jajanan menjadi salah satu penentu kecukupan gizi pada anak. Pada tahun 2007, Badan Pengawas Obat dan Makanan (BPOM) melakukan survei dengan melibatkan 4.500 sekolah di Indonesia dan membuktikan bahwa $45 \%$ jajanan anak berbahaya. Sebesar $45 \%$ produk pangan olahan siap saji di lingkungan sekolah tercemar baik fisik, mikrobiologis, maupun kimia. Selain tercemar mikroba, banyak produk pangan mengandung formalin, boraks, dan zat pewarna tekstil. Pusat Pengembangan Kualitas Jasmani Departemen Pendidikan Nasional mengakui bahwa selama ini masih banyak jajanan sekolah yang kurang terjamin kesehatannya dan berpotensi menyebabkan keracunan (Suci, 2009).

Temuan BPOM dalam sepuluh tahun terakhir (2006-2010) menunjukkan, sebanyak 48\% jajanan anak sekolah tidak memenuhi syarat keamanan pangan karena mengandung bahan kimia berbahaya. Bahan tambahan pangan (BTP) dalam jajanan sekolah telah melebihi batas aman serta cemaran mikrobiologi. Sedangkan 
berdasarkan pengambilan sampel pangan jajanan anak sekolah yang dilakukan di 6 ibukota provinsi (DKI Jakarta, Serang, Bandung, Semarang, Yogyakarta dan Surabaya), ditemukan $72,08 \%$ positif mengandung zat berbahaya. Temuan lain yang lebih mencengangkan lagi, berdasarkan data kejadian luar biasa (KLB) keracunan pangan yang dihimpun oleh Direktorat Surveilan dan Penyuluhan Keamanan Pangan - BPOM RI dari Balai Besar / Balai POM di seluruh Indonesia pada tahun 2008-2010 menunjukkan bahwa $17,26 \%-25,15 \%$ kasus terjadi di lingkungan sekolah dengan kelompk tertinggi siswa SD (Badan Intelegen Negara, 2012).

Tahun 2011, Badan POM juga telah melakukan sampling dan pengujian laboratorium terhadap Pangan Jajanan Anak Sekolah (PJAS) yang diambil dari 866 Sekolah Dasar / Madrasah Ibtidaiyah yang tersebar di 30 kota di Indonesia. Dari 4.808 sampel pangan jajanan anak sekolah, $1.705(35,46 \%)$ sampel diantaranya tidak memenuhi persyaratan keamanan dan atau mutu pangan (Safitri, 2014). Menurut data dari bidang Pencegahan dan Pemberantasan Penyakit (P2P) Dinas Kesehatan Kabupaten Malang tahun 2016, lima tahun terakhir ini terjadi enam kasus keracunan anak yang terjadi di lingkup sekolah. Kasus tersebut terjadi di Kecamatan Turen, Ngantang, Tirtoyudo, Tajinan, Dau, dan Gondanglegi. Keracunan tersebut terjadi dikarenakan anak mengkonsumsi jajanan di sekitar sekolah antara lain, keracunan rumput laut di toko sekitar sekolah, konsumsi cilok dan martabak mini, konsumsi sate usus, konsumsi mie pangsit, konsumsi biskuit yang sudah kadaluwarsa, serta konsumsi mie sedap dan telur ceplok.

Data sekolah yang terdapat kasus keracunan selama 5 tahun terakhir pada tahun 2016 terjadi di SDN 2 Turen dengan jumlah korban 6 anak, kedua terjadi pada tahun 2015 terjadi di SDN 03 Ngantang dengan jumlah korban 11 anak. Kasus ketiga terjadi di SDN 03
Purwodadi pada tahun 2015 dengan jumlah korban 18 anak. Kemudian pada tahun 2013 terjadi 3 kasus keracunan di SDN Gunung Ronggo Tajinan, SDN 2 Mulyoagung Dau , dan MI Wahid Hasyim Gondanglegi dengan masingmasing korban 21 anak, 13 anak, dan 8 anak.

Menurut data tersebut dapat disimpulkan bahwa keracunan pada anak yang terjadi diakibatkan kurangnya pengetahuan anak tentang jajanan / makanan yang sehat. Kurangnya pengetahuan dapat mempengaruhi perilaku seseorang termasuk perilaku kesehatan, sehingga bisa menjadi penyebab tingginya angka kejadian suatu penyakit. Pemberian pengetahuan kepada anak sekolah dasar dapat dilakukan dengan cara penyuluhan kesehatan (Maulana, 2012). Penyuluhan kesehatan adalah kegiatan pendidikan yang dilakukan dengan menyebarkan pesan, menanamkan keyakinan, sehingga masyarakat tidak hanya sadar, tahu, dan mengerti, tetapi juga mau dan dapat melaksanakan suatu anjuran yang ada hubungannya dengan kesehatan. (Supariasa, 2014).

Observasi awal yang telah dilakukan di SDN 2 Mulyoagung Kecamatan Dau Kabupaten Malang, ditemukan bahwa banyak pedagang kaki lima yang berjualan di sekitar sekolah. Setiap harinya tidak kurang dari 8 pedagang kaki lima yang berjualan di halaman depan SDN 02 Mulyoagung. Sebagian besar siswa membeli jajanan tersebut pada jam istirahat. Selain itu, jajanan yang dijual kebanyakan terbuka dan tidak ditutup ketika dijajakan, serta saus dan bumbu yang digunakan juga menggunakan warna yang mencolok. Berdasarkan uraian diatas, penulis melakukan penelitian mengenai pendidikan kesehatan melalui penyuluhan gizi dengan media minicard terhadap pengetahuan jajanan sehat pada siswa SDN 02 Mulyoagung.

\section{METODE}

Penelitian ini merupakan penelitian kuantitatif dengan rancangan penelitian 
pre-experiment untuk mengukur seberapa efektif perlakuan yang sudah diberikan, sedangkan model yang digunakan adalah one grup pretest posttest. Tidak ada kelompok pembanding (kontrol) dalam penelitian ini, tetapi sudah dilakukan observasi pertama dengan pretest sehingga memungkinkan adanya perubahan setelah adanya perlakuan. Dalam penelitian ini terdapat dua variabel yaitu variabel bebas berupa penyuluhan gizi menggunakan media minicard dan variabel bebterikat berupa pengetahuan mengenai jajanan sehat.

Populasi dalam penelitian adalah seluruh siswa SDN 02 Mulyoagung Kecamatan Dau Kabupaten Malang yang berjumlah 111 siswa. Sedangkan sampel dalam penelitian ini adalah siswa kelas IV dan V SDN 02 Mulyoagung sebesar 30 siswa. Teknik yang digunakan untuk menentukan sampel adalah purposive sampling. Instrumen yang digunakan dalam penelitian ini adalah alat penelitian (minicard) dan kuesioner. Pengumpulan data dalam penelitian ini menggunkan hasil pengamatan (observasi awal), wawancara, dan tes pengetahuan menggunakan kuesioner. Analisis data yang digunakan adalah uji statistik Two Related Sampel (Wilcoxon).

\section{HASIL}

\section{Identitas Responden}

Tabel 1 Hasil Pengukuran Tingkat Kebisingan Ekivalen (Leq)

\begin{tabular}{ccc}
\hline Umur & Frekuensi & Persentase \\
\hline 9 & 4 & 13.3 \\
10 & 14 & 46.7 \\
11 & 10 & 33.3 \\
12 & 2 & 6.7 \\
\hline Total & 30 & 100.0 \\
\hline
\end{tabular}

Penellitian ini dilakukan pada siswa kelas IV dan kelas V SDN 02 Mulyoagung Kecamatan Dau Kabupaten Malang. Berdasarkan Tabel 4.1 dapat diketahui bahwa jumlah responden (n) adalah sebesar 30. Dari 30 responden, paling muda berumur 9 tahun dan paling tua berumur 12 tahun. Dari data umur responden tersebut, $13,3 \%$ berumur 9 tahun yaitu sebanyak 4 responden; $46,7 \%$ berumur 10 tahun yaitu sebanyak 14 responden; $33,3 \%$ berumur 11 tahun yaitu sebanyak 10 responden; dan $6,7 \%$ berumur 12 tahun yaitu sebanyak 2 responden.

Tabel 4.2 Jenis Kelamin

\begin{tabular}{ccc}
\hline Jenis Kelamin & Frekuensi & Persentase \\
\hline Laki-laki & 19 & 63.3 \\
Perempuan & 11 & 36.7 \\
\hline Total & 30 & 100.0 \\
\hline
\end{tabular}

Dari Tabel 4.2 dapat diketahui bahwa responden terdiri atas $63,3 \%$ lakilaki yaitu sebanyak 19 responden dan
$36,7 \%$ perempuan yaitu sebanyak 11 responden. 
Tabel 4.3 Kelas Responden

\begin{tabular}{ccc}
\hline Kelas & Frekuensi & Persentase \\
\hline 4 & 14 & 46.7 \\
5 & 16 & 53.3 \\
\hline Total & 30 & 100.0 \\
\hline
\end{tabular}

Dari Tabel 4.3 dapat diketahui bahwa $46,7 \%$ responden yaitu sebanyak 14 siswa dari kelas 4 dan $53,3 \%$

\section{Data Skor Pre-test}

Data pre-test didapatkan sebelum perlakuan menggunakan media minicard. Diberikan soal dengan jumlah 22 butir soal. Subjek pre-test berjumlah 30 responden. Dari hasil tes pengetahuan tentang jajanan sehat didapatkan nilai rata-rata 60,6. Skor tertinggi yang didapatkan oleh responden penyuluhan adalah 82 dan skor terendah yang didapatkan adalah 36. Pada pengukuran awal test (pre- responden yaitu sebanyak 16 siswa dari kelas 5 .

Tabel 4.4 Distribusi Frekuensi Skor Pre-test

\begin{tabular}{ccc}
\hline Nilai & Frekuensi & Persentase \\
\hline 36 & 1 & 3.3 \\
41 & 2 & 6.7 \\
45 & 5 & 16.7 \\
55 & 3 & 10.0 \\
59 & 3 & 10.0 \\
64 & 4 & 13.3 \\
68 & 4 & 13.3 \\
73 & 4 & 13.3 \\
77 & 3 & 10.0 \\
82 & 1 & 3.3 \\
\hline Total & 30 & 100.0 \\
\hline
\end{tabular}

\section{Data Skor Post-test}

Data post-test didapatkan
setelah diberikan perlakuan
menggunakan media minicard. Hasil
dari post-test inilah yang nantinya
menjadi indikator peningkatan setelah

test), hanya ada 4 orang yang mendapatkan nilai baik (>75) dan antusias dalam menjawab pertanyaan kuesioner dari peneliti. Jawaban yang diberikan oleh siswapun juga banyak yang belum tepat sesuai dengan informasi yang akan diberikan dalam penyuluhan gizi menggunakan media minicard. Berikut adalah tabel frekuensi skor pre-test yang didapatkan. 
Alat peraga minicard meningkatkan pengetahuan yang baik pada siswa kelas IV \& V SDN 02 Mulyoagung mengenai materi jajanan sehat. Dari hasil tes pengetahuan tentang jajanan sehat, didapatkan nilai rata-rata sebesar 91,9.
Skor tertinggi yang didapatkan oleh responden penyuluhan adalah 100 dan skor terendah yang didapatkan adalah 73. Berikut adalah tabel frekuensi skor pre-test yang didapatkan

Tabel 4.5 Distribusi Frekuensi Skor Post-test

\begin{tabular}{ccc}
\hline Nilai & Frekuensi & Persentase \\
\hline 73 & 2 & 6.7 \\
82 & 3 & 10.0 \\
86 & 4 & 13.3 \\
91 & 6 & 20.0 \\
95 & 5 & 16.7 \\
100 & 10 & 33.3 \\
\hline Total & 30 & 100.0 \\
\hline
\end{tabular}

Dalam uji normalitas, terdapat dua hipotesis, yaitu (a) Hipotesis nihil $\left(\mathrm{H}_{0}\right)$, yang berbunyi 'data berdistribusi normal'; dan (b) Hipotesis alternatif (Ha), yang berbunyi 'data tidak berdistribusi normal'.

Pengambilan keputusan menggunakan nilai Asymp. Sig atau signifikansi $(\alpha)$ 0,05 . Apabila nilai signifikansi $(\alpha)>$ 0,05 maka $\mathrm{H}_{0}$ diterima dan $\mathrm{Ha}$ ditolak, dan apabila nilai signifikansi $(\alpha)<0,05$ maka $\mathrm{H}_{0}$ ditolak dan $\mathrm{Ha}$ diterima. $\mathrm{H}_{0}$ dalam penelitan ini adalah tidak terdapat peningkatan pengetahuan siswa SDN 02 Mulyoagung yang diberi penyuluhan mengenai jajanan sehat menggunakan minicard. Sedangkan $\mathrm{Ha}$ dalam penelitian ini berbunyi terdapat peningkatan pengetahuan siswa SDN 02 Mulyoagung yang diberi penyuluhan mengenai jajanan sehat menggunakan minicard

Tabel 4.6 Normalitas Data

\begin{tabular}{lcccccc}
\hline & \multicolumn{3}{c}{ Kolmogorov-Smirnov $^{\mathrm{a}}$} & \multicolumn{3}{c}{ Shapiro-Wilk } \\
\cline { 2 - 7 } & Statistic & df & Sig. & Statistic & Df & Sig. \\
\hline Nilai_Pre-test & .153 & 30 & .071 & .941 & 30 & .094 \\
Nilai_Post-test & .178 & 30 & .017 & .871 & 30 & .002 \\
\hline
\end{tabular}

Uji normalitas dalam penelitian ini menggunakan Kolmogorov-Smirnov Test karena jumlah sampel $\leq 30$ sampel. Dari Tabel 4.6 diketahui bahwa nilai Sig. pre-test sebesar 0,071. Hal ini berarti nilai tersebut lebih dari 0,05 sehingga $\mathrm{H}_{0}$ diterima dan $\mathrm{Ha}$ ditolak. Data tersebut berdistribusi normal. Nilai
Sig. post-test sebesar 0,017. Hal ini berarti nilai tersebut kurang dari 0,05 sehingga $\mathrm{H}_{0}$ ditolak dan $\mathrm{Ha}$ diterima. Data post-test tidak berdistribusi normal. Dengan demikian, uji hubungan dilakukan dengan menggunakan metode nonparametrik Wilcoxon. 
7 | Jurnal Preventia

Tabel 4.7 Ranks

\begin{tabular}{llccc}
\hline & & $\mathrm{N}$ & Mean Rank & Sum of Ranks \\
\hline \multirow{3}{*}{ Nilai_Post - Nilai_Pre } & Negative Ranks & $0^{\mathrm{a}}$ & .00 & .00 \\
& Positive Ranks & $30^{\mathrm{b}}$ & 15.50 & 465.00 \\
& Ties & $0^{\mathrm{c}}$ & & \\
\cline { 2 - 4 } & Total & 30 & & \\
\hline
\end{tabular}

Tabel 4.7 memaparkan nilai Mean Rank dan nilai Sum Rank dari data sampel. Dari data sampel terlihat semua sampel atau 30 sampel bernilai positif (positive rank) sebesar 30. Artinya nilai post-test 30 responden dalam penelitian ini mengalami peningkatan. Kemudian untuk negative ranks menunjukkan angka 0 , yang berarti tidak ada penurunan nilai dalam post-test penelitian ini. Selanjutnya nilai yang sama (ties) yaitu 0 , artinya tidak ada responden yang nilai pre-test dan post-test sama atau tidak mengalami peningkatan maupun penurunan nilai.

Tabel 4.8 Tes Statistik

Nilai_Post - Nilai_Pre

Asymp. Sig. (2-tailed)

.000

Kriteria pengujian dalam uji Wilcoxon adalah $\mathrm{H}_{0}$ ditolak jika analisis statistik hitung $<\alpha(0,025)$ dan $\mathrm{H}_{0}$ diterima jika analisis statistik hitung $>\alpha(0,025)$. Tabel 4.8 memaparkan hasil analisis hipotesis. Tabel tersebut menunjukkan bahwa nilai signifikansi yang dihasilkan adalah 0,000 . Hal ini berarti nilai

\section{PEMBAHASAN}

Insiden keracunan nasional yang terjadi pada tahun 2014 terbanyak disebabkan oleh makanan, dengan jumlah insiden 98 dari 120 insiden yang terjadi (BPOM, 2015). Menurut Koukel S, (2009) banyak iklan makanan yang menawarkan jajanan seperti keripik, kue kering, permen, dan minuman soda yang tidak termasuk pilihan jajanan yang baik. Penelitian yang dilakukan oleh Safriana (2012) menunjukkan bahwa 95 responden siswa Sekolah Dasar (SD) (64\%) mengaku terpengaruh dengan media iklan makanan. Hasil penelitian Yayasan Lembaga Konsumen Indonesia (YLKI) menyebutkan bahwa makanan jajanan anak SD yang berharga murah dan berbentuk makanan basah siap dikonsumsi yang dijual pedagang di tersebut kurang dari $\alpha(0,025)$ sehingga $\mathrm{H}_{0}$ ditolak dan $\mathrm{Ha}$ diterima. Dengan demikian, terdapat peningkatan pengetahuan siswa SDN 02 Mulyoagung yang diberi penyuluhan mengenai jajanan sehat menggunakan minicard.

sekitar lokasi sekolah masih dicampur dengan berbagai zat berbahaya (Muhilal, 2006).

Penelitian yang dilakukan oleh Putra (2009) 92,2\% responden membeli makanan jajanan pada saat jam istirahat sekolah. Hal ini berkaitan dengan salah satu alasan responden mengkonsumsi jajanan untuk mengurangi rasa lapar setelah beberapa jam belajar di kelas. Rasa lapar mengurangi kemampuan anak untuk merespon lingkungan, memperhatikan, dan memperoleh informasi (Chitra, 2006). Maka dari itu dibutuhkan pengetahuan yang baik tentang jajanan sehat agar anak bisa memilih jajanan sehat dengan tepat.

Pengetahuan manusia diperoleh melalui persepsinya terhadap stimulus dengan menggunakan alat indera 
(Hamida, 2012). Salah satu cara untuk dapat meningkatkan pengetahuan adalah dengan pendidikan kesehatan. Pendekatan dalam pemberian pendidikan kesehatan sangat banyak macamnya antara lain metode ceramah, demonstrasi, diskusi kelompok, dan lain-lain. Kegiatan penyuluhan merupakan salah satu upaya yang dilakukan dalam memberikan pendidikan kesehatan. Untuk membantu dan memperagakan dalam proses pendidikan kesehatan perlu adanya suatu media. Media dapat diketahui sangat membantu sasaran didik dalam menerima informasi berdasarkan kemampuan penangkapan panca indera (Wulandari, 2016).

Pendidikan gizi yang sering dilakukan masih dengan cara konvensional yaitu dengan metode ceramah karena menjadi dasar dari semua metode pembelajaran lain dan memiliki pengaruh yang signifikan terhadap peningkatan pengetahuan (Wulandari, 2007), namun cara ini terkadang membosankan sehingga diperlukan keterampilan dalam pelaksanaannya (Suryani, 2013). Pada metode ceramah ini pemateri memberikan presentasi secara lisan kemudian responden mencatat dan menanggapi penjelasan, sehingga responden cenderung pasif (Mulyatiningsih, 2010).

Peneltian yang dilakukan oleh Rawati (2014), diketahui tingkat pengetahuan siswa/I SDN Tanjung Selamat setelah dilakukan penyuluhan dengan media kesehatan tentang pengetahuan kebersihan gigi mengalami peningkatan. Hasil penelitian lain oleh Ida (2015), menyebutkan bahwa terjadi peningkatan nilai pengetahuan siswa kelas III SD yang mendapatkan penyuluhan dengan media kartu dibandingkan dengan siswa yang tidak mendapat penyuluhan. Hal tersebut menunjukkan bahwa kartu merupakan salah satu media yang baik dalam suatu pendidikan kesehatan. Menurut penelitian Maduretno (2015) diketahui bahwa penggunaan metode ceramah hanya dapat meningkatkan niat siswa dan siswa belum mengaplikasikan dalam praktik memilih pangan jajanan mereka. Kartu merupakan salah satu media visual yang dapat membantu dan menstimuasi indera mata (penglihatan). Oleh karena itu, maka dibentuklah suatu inovasi media penyuluhan gizi yaitu dengan menggunakan media flashcard (kartu bergambar).

Penelitian yang dilakukan oleh Dwi tahun 2010, pada pembahasannya menyebutkan dalam penelitian sebelumnya masih ada beberapa kelemahan, yaitu menggunakan flashcard yang tidak disertai dengan gambar atau malah menggunakan gambar yang terlalu besar dan kata yang terlalu kecil. Dalam hal ini indera penglihatan anak akan terfokus pada gambar yang bentuknya jauh lebih menarik daripada deretan huruf, materi yang seharusnya memberikan informasi tidak bisa diterima secara optimal. Sehingga dalam penelitian ini menggunakan media minicard, yaitu media flashcard yang telah dimodifikasi (diubah) ukurannya dan disesuaikan penggunaannya.

Menurut penelitian Sartika yang dilakukan tahun 2011 tentang Pengaruh Pendidikan Gizi Terhadap Perilaku Konsumsi Serat Pada Siswa dengan hasil penelitian yang menyatakan bahwa pendidikan gizi menggunakan kombinasi penyuluhan dan permainan dapat meningkatkan skor pengetahuan dan skor perilaku siswa. Media yang cocok digunakan adalah kartu bergambar (flashcard), cari kata (word search), dan simulasi makanan sumber serat. Hal ini sejalan dengan penelitian Sartika (2014) bahwa permainan edukatif seperti kartu bergambar (flashcard), alat menggambar, menggunting, menggambar, simulasi alat kebersihan diri dan bahan makanan dapat meningkatkan skor pengetahuan anak tentang praktek kebersihan diri dan makanan sehat bergizi.

Selain itu, Pratiwi (2015) juga menunjukkan hasil meningkatnya pengetahuan pada dua kelompok 
responden dalam penelitiannya setelah diberikan penyuluhan kesehatan menggunakan metode permainan edukatif maupun menggunakan metode ceramah. Peningkatan pengetahuan pada responden dikarenakan adanya kemauan responden untuk mengetahui tentang materi yang diberikan dengan lebih rinci,sehingga mereka antusias mengikuti penyuluhan tersebut.

Penelitian ini memperlihatkan peningkatan nilai pengetahuan responden setelah dilakukan penyuluhan. Salah satu faktor yang mempengaruhi meningkatnya pengetahuan adalah adanya informasi yang telah diterima (Lestari, 2015). Media massa dapat membawa pesanpesan yang sugesti yang dapat mengarahkan opini seseorang. Informasi baru yang didapatkan dari media massa dan lembaga pendidikan dapat mengarahkan pendapat seseorang sehingga dapat memberikan landasan kognitif baru bagi terbentuknya sikap yang positif (Tampubolon, 2009).

Penelitian Rogers (1983) dalam

Hafni (2011) mengungkapkan bahwa keputusan tentang inovasi yaitu: pengetahuan, persuasi, keputusan, pelaksanaan, dan konfirmasi. Melalui pendidikan kesehatan dengan alat permainan minicard ini dapat meningkatkan pengetahuan dimana responden diarahkan untuk memahami eksistensi. Pada tahap ini, responden diberikan informasi mengenai jajanan sehat agar pengetahuannya dapat meningkat. Setelah pengetahuannya meningkat diharapkan sikap dan tindakannya juga meningkat kearah yang positif.

Melalui pendidikan kesehatan yaitu penyuluhan gizi ini, setelah mendapat informasi mengenai jajanan sehat responden mulai tertarik untuk lebih lanjut mengetahui manfaat mengkonsumsi jajanan sehat melalui media minicard. Untuk dapat mengetahui manfaat tersebut apa saja, individu yang bersangkutan harus mampu menyerap, mengolah, dan memahami informasi yang diterima sebagai stimulus. Setelah dilakukan pengukuran awal terhadap pengetahuan siswa tentang jajanan sehat, dilakukan penyuluhan gizi dengan menggunakan media minicard, dan dilakukan pengukuran kembali terhadap pengetahuan untuk melihat apakah ada perubahan peningkatan atau tidak. Pada tahap akhir penilaian, semua responden dalam penelitian ini menunjukkan peningkatan pengetahuan yang sudah dibuktikan dengan meningkatnya nilai pre-test ke post-test.

Media ini dapat meningkatkan perhatian, konsentrasi, dan ingatan anak. Sehingga anak tersebut diharapkan mulai belajar menerapkan hal yang dipelajari dan akhirnya dapat membentuk pengetahuan yang baik dalam pemilihan jajanan sehat. Hal ini dikarenakan kesadaran dan ketertarikan siswa terhadap media minicard tentang jajanan sehat, materi yang diberikan sesuai dengan kebutuhan siswa, dan metode serta media penyampaian informasi yang jelas.

Hasil nilai pengetahuan dari penelitian ini dapat disimpulkan bahwa rata-rata skor pengetahuan pada pada pengukuran awal (pre-test) < rata-rata skor pengetahuan pada pada pengukuran awal (post-test). Berdasarkan hasil nilai pengetahuan siswa terdapat peningkatan rerata (mean) pengetahuan setelah diberikan penyuluhan gizi dengan media minicard dari yang awalnya nilai ratarata sebesar 60, 6 menjadi 91,9. Setelah dilakukan intervensi responden telah mengetahui pengertian jajanan sehat, ciri jajanan sehat, jenis jajanan sehat, cara memilih jajanan sehat, dampak jajanan yang tidak sehat, menghindari jajanan yang tidak sehat, dan cara mencuci tangan yang benar. Hal ini sejalan dengan penelitian yang dilakukan oleh Wulandari (2016), bahwa ada peningkatan pengetahuan, sikap, dan praktik pemilihan pangan jajanan anak sekolah dasar sebelum dan sesudah pemberian media smartcards pada siswa SDN Sekaran 02.

Peningkatan pengetahuan yang lebih besar pada nilai posttest dengan 
selisih nilai sebesar 31,3 disebabkan adanya hubungan penggunaan media minicard sebagai media pendidikan kesehatan melalui penyuluhan gizi. Menurut Arsyad (2010), melalui gambar siswa mampu mengenal dan menanggapi masalah kesehatan yang ada sesuai dengan informasi yang didapatkan melalui media. Media berupa kartu bergambar merupakan hal positif dalam mendorong peningkatan pengetahuan dan sikap terhadap objek tertentu (Tatminingsih, 2010), dalam penelitian ini objek adalah jajanan sehat. Hal ini didukung oleh hasil penelitian Setiyono (2010), yang menyimpulkan bahwa penggunaan media bergambar efektif dalam promosi kesehatan pencegahan dini kelainan refraksi pada siswa sekolah dasar.

Penelitian yang dilakukan oleh Wulandari, dkk (2007) membuktikan bahwa flashcard efektif untuk menyampaikan pesan atau informasi kesehatan tentang penyakit kecacingan. Presska (2012) dalam penelitiannya juga menjelaskan bahwa dengan metode cerita bergambar dan ceramah juga meningkatkan pengetahuan responden tentang kecacingan. Selain itu Marlyn, dkk (2012) pada penelitiannya menyimpulkan bahwa penggunaan media flashcard lebih efektif daripada penggunaan media kartu kata sebagai media promosi kesehatan dalam meningkatkan pengetahuan dan sikap tentang penyakit cacingan pada anak SDN 01 Karangduren di desa Karangduren.

Hasil penelitian lain yaitu Aprilaz (2016), menunjukkan bahwa pendidikan kesehatan dengan metode atau media apapun dapat meningkatkan pengetahuan responden. Peningkatan pengetahuan setelah diberikan penyuluhan gizi sesuai dengan tujuan pendidikan kesehatan yaitu terjadi perubahan pengetahuan yang nantinya diharapkan diiringi dengan perubahan sikap, dan tingkah laku individu, keluarga, kelompok khusus, dan masyarakat dalam membina serta memelihara perilaku hidup sehat serta berperan aktif dalam upaya mewujudkan derajat kesehatan yang optimal. Peningkatan pengetahuan responden setelah diberikan penyuluhan dipengaruhi oleh beberapa faktor, salah satunya adalah informasi. J. Guilbert menyebutkan ada 4 faktor yang mempengaruhi proses belajar yaitu materi yang dipelajari, lingkungan, instrumen, dan kondisi penerima materi (Nursalam dan Efendi, 2008).

Syofia (2014) dalam penelitian yang dilakukannya juga menyimpulkan bahwa terjadi peningkatan pengetahuan siswa setelah dilakukan penyuluhan dengan flashcard. Perubahan pengetahuan yang diperoleh merupakan hasil dari penyuluhan dengan media minicard. Media minicard ini sudah dimodifikasi berisi gambar dan informasi tentang jajanan sehat sehingga anak mengalami ketertarikan untuk memahami. Menurut penelitian Saputri (2011) pemberian informasi dengan media yang menarik dan suasana yang menyenangkan sesuai dengan tahap perkembangan kognitif anak usia sekolah yang mayoritas respondennya berumur $10 \& 11$ tahun berada dalam tahap operasional konkrit artinya aktivitas mental yang difokuskan pada objek-objek peristiwa nyata atau konkrit.

\section{KESIMPULAN}

Berdasarkan hasil penelitian dan analisis data mengenai efektivitas penyuluhan menggunakan media minicard, kesimpulan dalam penelitian ini adalah terjadi peningkatan nilai ratarata nilai pengetahuan pada post-test setelah diberikan intervensi berupa penyuluhan gizi dengan minicard, sehingga penyuluhan menggunakan media minicard efektif dalam meningkatkan pengetahuan tentang jajanan sehat pada siswa kelas IV \& kelas V SDN 02 Mulyoagung. Selain itu, juga menciptakan media minicard dengan materi jenis dan ciri jajanan sehat pada siswa kelas IV \& V SDN 02 Mulyoagung. 


\section{SARAN}

Setelah diadakannya penyuluhan ini diharapkan siswa dapat mengingat informasi yang telah diberikan dan nantinya memberikan sikap yang positif dalam memilih jajanan yang ada di sekolah sehingga mengurangi paparan anak sekolah terhadap makanan jajanan yang tidak sehat dan tidak aman.

\section{DAFTAR PUSTAKA}

Aprilaz, Istiqomah. 2016. Perbandingan Efektivitas Antara Metode Video Dan Cerita Boneka dalam Pendidikan Seksual Terhadap Pengetahuan Anak Prasekolah Tentang Personal Safety Skill. Skripsi. Program Studi Ilmu Keperawatan Fakultas Kedokteran dan Ilmu Kesehatan Universitas Islam Negeri Syarif Hidayatullah Jakarta

Arsyad, A. 2010. Media Pembelajaran. Raja Grafindo Persada. Jakarta

Badan Intelegen Negara. 2012.

Penyuluhan Keamanan Pangan. Diakses pada 20 Oktober 2016 online dalam http://www.bin.go.id

Badan Pengawas Obat dan Makanan RI. 2010. Sistem Keamanan Pangan Terpadu. Diakses pada 20 Oktober 2016 online dalam http://www.pom.go.id

Badan Pengawas Obat dan Makanan RI. 2015. Insiden Keracunan Nasional Tahun 2014. Diakses pada 13 Agustus 2017. Online dalam http://www.pom.go.id

Chitra U., Reddy CR. 2006. The Role of Breakfast In Nutrient Intake of Urban School Children. Public Health Nutrition Volume 10 (1) hal. 55-58

Dinas Kesehatan Kabupaten Malang. 2016. Data Keracunan Anak Sekolah 5 Tahun Terakhir. Malang

Dwi, Selvy. 2010. Efektivitas Penggunaan Metode Glenn Doman dalam Bentuk Flashcard terhadap Peningkatan
Kemampuan Membaca Anak Cerebral Palsy di SLB D YPAC Surakarta Tahun ajaran 2009/2010. Skripsi. Fakultas Keguruan dan Ilmu Pendidikan. Universitas Sebelas Maret. Surakarta

Fudyartanta, Ki. 2012. Psikologi Perkembangan. Pustaka Pelajar. Yogyakarta

Hafni, Z. 2011. Pengaruh karakteristik Inovasi Dan Sistem Sosial Terhadap Adopsi Inovasi Program Bina Keluarga Balita (BKB) di Kelurahan Kwala Bingai Kecamatan Stabat Kabupaten Langkat. Diakses pada tanggal 13 Agustus 2017 online dalam http://www.respository.isi.ac.id/ bitstream/123456789/30598/3/C hapter\%20II.pdf

Hamida, Khairuna. 2012. Penyuluhan Gizi dengan Media Komik Untuk Meningkatkan Pengetahuan Tentang Keamanan Makanan Jajanan, Jurnal Kesehatan Masyarakat Fakultas Ilmu Kesehatan Universitas Muhammadiyah Surakarta KEMAS volume 8 (1) (2012) hal. 67-73

Hasdianah, dkk. 2012. Gizi, Pemanfaatan Gizi, Diet, dan Obesitas. Nuha Medika. Yogyakarta

Kementerian Kesehatan RI. 2015. Rencana Strategis Kementerian Kesehatan Tahun 2015-2019. Jakarta

Koukel S. 2009. Choosing Health Snacks For Children. Extension Faculty Health, Home, and Family Development University of Alaska Fairbanks. Diakses tanggal 13 Agustus 2017 online dalam http://www.uaf.edu

Lestari, Shinta Asih Witha. 2015. Pengaruh Penyuluhan Jajanan Sehat Terhadap Pengetahuan dan Sikap Siswa di Madrasah Ibtidaiyah Gonilan Kartasura, Naskah Publikasi. Fakultas 
Kedokteran Universitas Muhammadiyah Surakarta.

Lindsay AC., Sussber KM., Kim J., Gortmaker S. 2006. The Role of Parents in PreventingChilhood Obesity, Harvard School of Public Health Volume 16 No 1 Spring. Diakses pada 13 Agustus 2017 online dalam http://www.Futureofchildren.org /usr doc/08 5562 lindsayetal.pdf

Lin W., Yang HC., and Pan WH. 2007. Nutrition Knowledge, Attitude, and Behaviour of Taiwanese Elementary School Children, Asia Pacific Journal Clinical Nutrition Volume 16 (S2) : 534546. Diakses pada tanggal 13 Agustus 2017 online dalam http://www.apjen.nhri.org.tw/ser ver/APJN/Volume16/Vol16supp 1.2/(534-546)weilin.pdf

Maduretno, I.S. 2015. Niat dan Perilaku Pemilihan Jajanan Anak Sekolah yang Mendapat Pendidikan Gizi Metode Ceramah dan TGT. Indonesian Journal of Human Nutrition, Volume 2 (1)

Maulana, Heri. D. J. 2012. Promosi Kesehatan. EGC. Jakarta

Marlyn, Maisje. 2012. Efektivitas Flashcard dan Kartu Kata dalam Meningkatkan Pengetahuan dan Sikap tentang Penyakit Cacingan di Sekolah Dasar di Desa Karang Duren Kecamatan Sokaraja Banyumas

Muhilal, Damayanti D. 2006. Gizi

Seimbang Untuk Anak Sekolah Dasar Dalam Hidup Sehat Dalam Siklus Kehidupan Manusia. Gramedia Pustaka Utama. Jakarta.

Mulyatiningsih, E. 2010. Pembelajaran Aktif, Kreatif, Inovatif, Efektif, dan Menyenangkan (PAIKEM) hal. 14-21. Universitas Negeri Yogyakarta. Diakses 12 Agustus 2017 online pada http://www.staff.uny.ac.id

Murphy, SP., Constance Gewa, C.
Grillenberger, M., Bwibo, NO.,

Neumann, CG. 2007.

Designing, Snacks to Address Micronutrient Deficiencies in Rural Kenyan Schoolchildren. J. Nutr. 137 : 1093-1096

Nam-E Kang. 2010. Food Safety

Knowledge And Practice by the Stages of Change Model in School Children, Nutrition Research and Practice, Volume 4 (6), hal 535-540

Nursalam dan Efendi, Ferry. 2008.

Pendidikan dalam

Keperawatan. Salemba Medika. Jakarta.

Peilin, H. 2004. Factors Influecing Students Decisions To Choose Healthy Or Unhealthy Snacks At The University of Newcastle, Australia. Journal of Nursing Research, Vol. 12 no 2 hal. 8391.

Pratap BO, Booluck BJH. 2006.

Children's Consumption of Snack at School in Mauritius. Nutrition and Food Science, 35 :15-19

Pratiwi, Dita Anugrah. 2015. Pengaruh Penyuluhan Metode Edukatif dan Metode Ceramah Terhadap Pengetahuan, Sikap, dan Tindakan Tentang Pencegahan Penyakit Diare Pada Murid SD di Kecamatan Poasia Kota Kendari Tahun 2015. Jurnal Ilmiah Fakultas Kesehatan Masyarakat Universitas Halu Oleo 2015 : 2-3

Presska, Cecilia. 2012. Pengaruh Penyuluhan Kesehatan Tentang Kecacingan Terhadap Pengetahuan dan Sikap Siswa Madrasah Ibtidaiyah An Nur Kelurahan Pedurungan Kidul Kota Semarang, Jurnal Promosi Kesehatan Indonesia VII (2) hal. 184-190

Putra, Andhika Eka. 2009. Gambaran Kebiasaan Jajan Siswa di Sekolah Dasar Hj. Isriati Semarang, Artikel Penelitian. Program Studi Ilmu Gizi 
13 | Jurnal Preventia

Fakultas Kedokteran Universitas Diponegoro

Rawati, Siregar. 2014. Efektivitas

Penyuluhan dengan Media Poster Terhadap Peningkatan Pengetahuan Tentang Kesehatan Gigi pada Siswa SDN Tanjung Selamat, Jurnal Ilmiah PANNMED, Volume 9 (2), hal 166-169

Safitri, Cynthia H. 2014. Perbedaan

Metode Team Game

Tournament dan Ceramah Terhadap Peningkatan Pengetahuan Pemilihan Jajanan Sehat, Indonesian Journal of Human Nutrition, Vol. 1 No.2 : 89-105

Safriana. 2012. Perilaku Memilih Jajanan pada Siswa Sekolah Dasar di SDN Gorot Kecamatan Darul Imalah Kabupaten Aceh

Saputri, Lila Oktania. 2011.

Peningkatan Pengetahuan dan Sikap dalam Pemilihan Jajanan Sehat Menggunakan Alat Permainan Edukatif Ular Tangga. Fakultas Keperawatan Universitas Airlangga. Surabaya

Sartika, Ratu A.D. 2011. Pengaruh Pendidikan Gizi Terhadap Pengetahuan dan Perilaku Konsumsi Serat Pada Siswa, Jurnal Ilmu Pendidikan, Jilid 17, Nomor 4 : hal 329-330

Sartika, 2014. Peningkatan

Pengetahuan Dan Sikap Dalam

Pemilihan Jajanan Sehat Menggunakan Alat Permainan Edukatif Ular Tangga. Artikel Ilmiah, Fakultas Keperawatan Universitas Airlangga, Surabaya.

Setiyono, B. 2010. Efektivitas Media Komik dalam Promosi Pencegahan Dini Kelainan Refraksi pada Siswa Sekolah Dasar. Sekolah Pascasarjana Universitas Gadjah Mada. Yogyakarta

Sihadi. 2004. Makanan Jajanan Bagi Anak Sekolah. Jurnal Kesehatan YARSI
Suci, Eunike S.T. 2009. Gambaran Perilaku Jajan Murid Sekolah Dasar di Jakarta. Jurnal Vol 1 No. 1 : hal 29-30 Diakses pada 22 Oktober 2016 online dalam http://www.lib.ui.ac.id

Supariasa, I Dewa N. 2014. Pendidikan \& Konsultasi Gizi. EGC. Jakarta Suryani. 2013. Efektivitas Pembelajaran Kooperatif Tipe Team Game Tournament (TGT) dan Numbered Heads Together (NHT) Terhadap Keaktifan dan Hasil Belajar Matematika Siswa Kelas VII SMP Muhammadiyah 8 Yogyakarta, Skripsi. Fakultas Sains dan Teknologi Universitas Islam Negeri Sunan Kalijaga Yogyakarta. Diakses pada 12 Agustus 2017 online dalam http://www.digilib.uin$\underline{\text { suka.ac.id }}$

Syofia. 2014. Pengaruh Penyuluhan

Makanan Bergizi Beragam Seimbang dan Aman dengan Menggunakan Flash Card dalam Meningkatkan

Pengetahuan dan Sikap Anak Kelas 1-3 SD Islam Titi Berdikari Kecamatan Medan Labuhan Tahun 2014. Departemen Gizi Masyarakat. Fakultas Kesehatan Masyarakat Universitas Sumatera Utara. Medan

Tampubolon, F 2009, Pengaruh

Media Visual Poster Dan Leaflet Makanan Sehat Terhadap Perilaku Konsumsi Makanan Jajanan Pelajar Kelas Khusus SMAN 1 Panyabungan Mandailing Natal, diakses 13 Agustus 2017 online dalam http://repository.usu.ac.id/handl e/123456789/25162?mode=full \&submit_simple=Show + full+ite m+record

Tatminingsih, S. 2010. Permainan Sederhana Berguna Luar Biasa (Modifikasi Permainan Tradisional sebagai Sarana Pengembangan Kemampuan 
Anak), Jendela , Jurnal Psikologi Anak Indonesia, Edisi 02 hal. 3

WHO. 2006. Consultation to Develop a Strategy to Estimate the Global Burden of Foodborn Disease. Diakses pada tanggal 13 Agustus 2017 online dalam http://www.who.int

Wulandari A. 2007. Peningkatan

Pengetahuan Gizi pada Anak Sekolah Dengan Metode Ceramah dan Role Play, Skripsi. Fakultas Kedokteran Universitas Diponegoro.

Semarang. Diakses pada tanggal 12 Agustus 2017 online dalam http://eprints.undip.ac.id

Wulandari, D., Trianisa K., Abswari,

FR., Fendi R. 2007. Flashcard

Klasifikasi Dengan Sistem

Permainan Bridge Untuk

Meningkatkan Hasil Belajar

Sistem Klasifikasi Makhluk

Hidup Pada Siswa SMA

Wulandari, Ratna. 2016. Efek

Smartcards

Dalam

Meningkatkan Pengetahuan,

Sikap, Dan Praktik Dalam

Memilih Pangan Jajanan.

Journal Of Health Education.

Unnes Journal Of Public

Health. JHE 1 (1) 2016 
Santoso, dkk, Peningkatan Pengetahuan Siswa Mengenai Jajanan Sehat |14 